\title{
The Dimension "Time" in Two Hispanic Novelists (Alejo Carpentier y Manuel Vázquez-Bigi)
}

\section{La dimensión "tiempo" en dos novelistas hispanos (Alejo Carpentier y Manuel Vázquez-Bigi)}

\section{Dan Munteanu Colán ${ }^{1}$}

The dimension of time sometimes combined with that of space (thus embodying the concept of "chronotope," as Mikhail Bakhtin defined it) is a recurrent theme in literature, especially since the $19^{\text {th }}$ century; therefore, many modern and contemporary writers approached it from various points of view, suggesting different interpretations. During the last century, the great representatives of the Latin American Boom paid a special attention to this literary issue, as we may witness (re)reading their masterpieces. In order to prove this particular interest, this essay analyzes the work of two novelists, belonging to different generations, cultural environments and occupations, but also very different as far as their own style of writing, aesthetic approach, artistic language and specific narrative strategies are concerned. These two are the Cuban Alejo Carpentier and the Argentine Manuel Vázquez-Bigi. [Article copies available for a fee from The Transformative Studies Institute. E-mail address: journal@transformativestudies.org Website: http://www.transformativestudies.org (02019 by The Transformative Studies Institute. All rights reserved.]

KEYWORDS: Time, Temporal Dimension, Literature, Latin American Boom, Syncretism.

La dimensión tiempo es un tema recurrente en la literatura universal. Aristóteles definía ya en su Poetica la noción del tiempo dramático y del tiempo épico. Dicotomía que mucho más tarde aplicaría Joyce en su Ulises, en el siglo pasado. Este mismo siglo, Bajtin (1989) teoriza sobre el concepto de cronotopo, unidad espacio-tiempo, categorías inherentes a la conciencia del ser humano, en la acepción kantiana, pero, según Bajtin, generadas por la materialidad del mundo, analizables desde un

\footnotetext{
${ }^{1}$ Dan Munteanu Colán. Biography available at end of article. Address correspondence to: Dan Munteanu Colán; e-mail: danmunteanucolan@gmail.com.
} 